\title{
Characterisation and Pattern of Culling in Holstein Dairy Cows in Torbat-E-Jam Area, Northeast of Iran
}

\author{
Masood Didarkhah (Corresponding author) \\ Dept. Of Animal Science, International Campus, Ferdowsi university of Mashhad, Iran \\ Tel: 98-915-328-6938Ｅ-mail: masooddidar@yahoo.com
}

Mohsen Danesh Mesgaran

Dept. of Animal Science, Faculty of Agriculture, Ferdowsi university of Mashhad, Iran Tel: 98- 511-879-5618Ｅ-mail: danesh@um.ac.ir

Elias Ibrahimi Khorram Abadi

Dept. of Animal Science, Faculty of Agriculture, Ferdowsi university of Mashhad, Iran Tel: 98-915-328-7866_E-mail: eliiass378@gmail.com

Fereshteh Jamili

Dept. Of Animal Science, International Campus, Ferdowsi university of Mashhad, Iran Tel: 98-915-130-2144Ｅ-mail: mdfg1360@gmail.com

Seyed Mohammad Hosseini

Department of Animal Sciences, Faculty of Agriculture

University of Birjand, Iran

Received: July 5, 2013 Accepted: July 20, 2013

doi:10.5296/jas.v1i2.3957ＵRL: http://dx.doi.org/10.5296/jas.v1i2.3957 


\section{Abstract}

To describe proportion and pattern of culling in commercial dairy herds of Torbat-e-Jam region in northeastern of Iran, this survey was carried out over a period of 15 years from 1997 to 2011 in industrialized dairy herd. In total, the data of 4149 lactating cows have been used in this study. Overall, $415(09.0 \%)$ cows were culled. The involuntary culling were mainly from infertility or reproductive disorders $(4 \%)$, followed by metabolic and digestive disorders $(3 \%)$, infection disease (1\%) and lameness (1\%). Infertility accounted for 55\% of disposals in culled cows. Milk fever was the most important reason (26\%) for culling due to metabolic and digestive track disorders. Pneumonia was the most common infectious disease that contributed to culling, and on average, it was responsible for $43 \%$ of disposals. Subacute mastitis accunted $88 \%$ of infection disease disposal. Bone fracture, vagal syndrome and foreign body accunted $19 \%, 31 \%$ and $38 \%$ of other disorders disposal, respectively. Aproximately, $13 \%$ of the recorded cullings were for unknown reasons. High proportion of infertility or reproductive culling specially poor fertility should be considered as an important economic loss and precaution measures are necessary to reduce this loss.

Keywords: Culling, Holstein dairy herds, Torbat-e-Jam, Iran

\section{Introduction}

One of the critical goals in dairy farm husbandry is economic profit via mainly increase in milk and calf production. Culling management is one of the most important determinants of this goal (Alliare et al., 1977; Van Arendonk, 1985; Azizzadeh, 2011). Culling is complex issue, and many factors are involved. Dairy cows may be culled for either involuntary reason (i.e., death, acute disease, infertility) or voluntary reason (i.e., low yield). Both biology and management affect the decision to cull. When making a decision, the dairy farmer consider five major reasons: illness, low milk yield, conception status, stage of lactation, and parity. Culling potentially increase profits or reduce costs throught the replacement of sick or open cows that are expensive to keep and may die or through the replacement of low yielding cows. The culling rate which varies from herd to herd, depends on input and output price, yields, seaosenal variation of price, incidence of disease, and other variable factors (McCullough, 1996b; Van Arendonk, 1985; Van Arendonk, 1988; Grohn et al., 1997).

There are 15541 commercial dairy herds with 1719798 high yielding dairy cows in iran (www.amar.org.ir). Although a few number of studies have investigated pattern of culling, further knowledge of factors controling culling may lead to development of programs for better manage of culling under Iranian dairy farming conditions. So current study was designed to assess Characterisation and pattern of culling in commercial dairy herds in Torbat-e-Jam, one of the biggest dairy producing region in Iran, Khorasan Razavi Province.

\section{Material and Methods}

The study was performed in Khorasan Razavi Province, Torbat-e-Jam area, which is one of the most important centre of dairy product manufacturing located in Northeast of Iran. A commercial dairy farm milking Holstein cattle were used in this study. Herd sizes were 4149 lactating cows for 15 years period. This herd were used because of the completeness of it's 
records and farmer compliance. The herd had a full time on-staff veterinarian and the program of regular visit for pregnancy diagnoses, reproductive management and treatment of sick animals under direction of veterinarians. All milking cows, were housed in open-shed barns and fed on total mixed rations (corn silage, alfalfa hay and concentrates). The study population was composed of all lactating cows presented in dairy herds between 1997 to 2011 (Table 1). Calves and heifers were not included in the study. Primary reasons for culling were broadly categorized into 5 groups. Definition of each culling reason used in this study is shown in Table 2.

Table 1 . The study population

\begin{tabular}{|c|c|c|c|c|c|c|}
\hline Years & $1997-1999$ & $2000-2002$ & $2003-2005$ & $2006-2008$ & $2009-2011$ & Total \\
\hline Total & 654 & 870 & 895 & 865 & 865 & 4149 \\
\hline
\end{tabular}

Table 2. Definition of culling reasons categories

\begin{tabular}{|c|c|}
\hline Category & Definition \\
\hline $\begin{array}{l}\text { Metabolic and Digestive } \\
\text { Track Disorders }\end{array}$ & $\begin{array}{l}\text { Bloat, Acidosis, Lameness, Milk Fever, Ketosis, Displaced Abomasum, } \\
\text { Diarrhea }\end{array}$ \\
\hline $\begin{array}{l}\text { Infertility or Reproductive } \\
\text { Disorders }\end{array}$ & $\begin{array}{l}\text { Failure to conceive or reproductive disorder includes Infertility, Abortion, } \\
\text { Calving difficulties, Prolapse, Stillbirth, Dystocia }\end{array}$ \\
\hline Infection Disease & Hydatid cyst, Parasitic Disease, Pneumonia, Pulmonary Abscess \\
\hline Udder Disorders & $\begin{array}{l}\text { Subacute mastitis, Udder health problem (Ruptured Suspensory Ligaments, } \\
\text { Teat Injuries) }\end{array}$ \\
\hline Other Disorders & Bone Fracture, Vagal Syndrome, Foreign Body, Unknown \\
\hline
\end{tabular}

\section{Results}

In total, the data of 4149 lactating cows have been used in this study. Overall, $415(09.0 \%)$ cows were culled in 15-years period (Fig 1). Infertility or reproductive and metabolic or digestive track disorders represented $4 \%$ and $3 \%$ of the disposals respectively (Fig 1). The proportion of Udder disorders and other infection disease was 1\% (Fig 1). The most frequent primary involuntary culling reasons in culled lactating cows were: infertility or reproductive disorders (47\%), metabolic and digestive track disorders (28\%) and infection disease (13\%) 


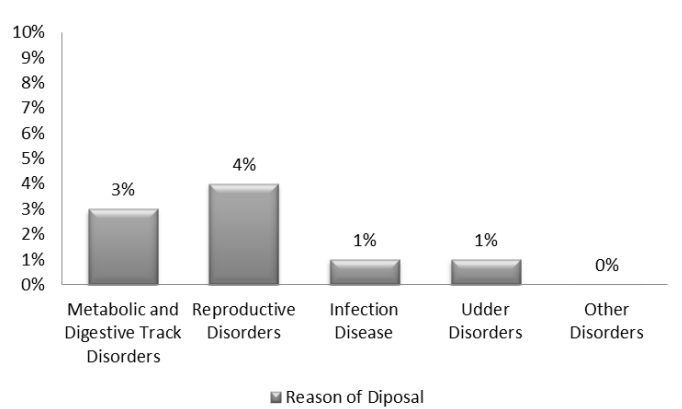

Fig 1: The percent of culled cows due to health problems in Torbat-e-Jam area, Iran

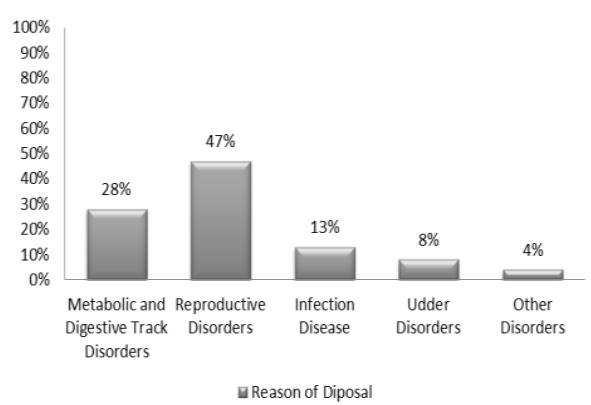

Fig 2: The proportion of helth problems that contributed to culling in Torbat-e-Jam area, Iran (1997-2011).

(Fig 2). Udder and other disorders proportions in the present study was $8 \%$ and $4 \%$, respectively (Fig 2). Milk fever was the most important reason (26\%) for culling due to metabolic and digestive track disorders (Table 3). Diarrhea (17\%) and bloat (16\%) were the next reasons for metabolic and digestive track disposal. Infertility accounted for $55 \%$ of disposals in culled cows (Table 4).

Table 3. Effect of Metabolic and Digestive Track Disorders on The Percentage of Culling

\begin{tabular}{|c|c|c|c|c|c|c|c|}
\hline Disorders & Years & 1997-1999 & $2000-2002$ & 2003-2005 & 2006-2008 & 2009-2011 & $1997-2011$ \\
\hline \multicolumn{2}{|l|}{ Bloat } & $11 \%(02)$ & $20 \%(01)$ & $30 \%(08)$ & $22 \%(08)$ & $00 \%(00)$ & $16 \%(19)$ \\
\hline \multicolumn{2}{|l|}{ Acidosis } & $11 \%(02)$ & $00 \%(00)$ & $00 \%(00)$ & $05 \%(02)$ & $14 \%(04)$ & $07 \%(08)$ \\
\hline \multicolumn{2}{|l|}{ Lameness } & $11 \%(02)$ & $00 \%(00)$ & $04 \%(01)$ & $16 \%(06)$ & $24 \%(07)$ & $14 \%(16)$ \\
\hline \multicolumn{2}{|l|}{ Milk Fever } & $11 \%(02)$ & $40 \%(02)$ & $44 \%(12)$ & $24 \%(09)$ & $17 \%(05)$ & $26 \%(30)$ \\
\hline \multicolumn{2}{|l|}{ Ketosis } & $17 \%(03)$ & $00 \%(00)$ & $04 \%(01)$ & $03 \%(01)$ & $07 \%(02)$ & $06 \%(07)$ \\
\hline \multicolumn{2}{|l|}{ Diarrhea } & $17 \%(03)$ & $20 \%(01)$ & $15 \%(04)$ & $14 \%(05)$ & $24 \%(07)$ & $17 \%(20)$ \\
\hline \multicolumn{2}{|c|}{ Disp Abomasum } & $11 \%(02)$ & $00 \%(00)$ & $00 \% 00)$ & $14 \%(05)$ & $10 \%(03)$ & $09 \%(10)$ \\
\hline \multicolumn{2}{|l|}{ Fatty Liver } & $11 \%(02)$ & $20 \%(01)$ & $04 \%(01)$ & $03 \%(01)$ & $03 \%(01)$ & $05 \%(06)$ \\
\hline \multicolumn{2}{|l|}{ Total } & $100 \%(18)$ & $100 \%(05)$ & $100 \%(25)$ & $100 \%(37)$ & $100 \%(29)$ & $100 \%$ \\
\hline
\end{tabular}

However, prolapse (36\%) and abortion (25\%) had a significant impact on infertility or reproductive disposal. Pneumonia was the most common infectious disease that contributed to culling, and on average, it was responsible for $43 \%$ of disposals (Table 5). Subacute mastitis remained the single most important reason (88\%) for udder disposal (Table 6). Bone fracture, vagal syndrome and foreign body accunted 19\%, 31\% and 38\% of other disorders disposal, respectively (Table 7). Aproximately, $13 \%$ of the recorded culling were for unknown reasons. Totally, Infertility, Palsy, pneumonia, subacute mastitis and foreign body were the major reasons for culling of cows in the studied herd. 


\section{Discussion}

Culling is one of the most complex decisions dairy farmers make on an almost day-to-day basis. In general, both biological and managerial factors can impress dairy farmers decisions. The major aspects considered in culling decisions are parity, health status, fertility status, milk yield status, and stage of lactation as well as the value of the replacement animal and it's cost (Allaire et al.,1977; Cobo-Abreu et al.,1979b; Milian-Suazo et al.,1988). Beaudeau et al. (1993) estimated that more than half of all cullings are associated with health disorders. Out of 15 health disorders studied in Finnish Ayrshire cows, all except retained placenta had an impact on culling (Rajala-Schultz and Gröhn, 1999a). Morbidity plays a significant role in culling decisions and the economic impact on the profitability of a herd will be considered especially at the time when the farmer is deciding whether to keep the cow or cull her (Gröhn et al., 2003). Indirect effects of diseases on culling are manifested through decreased milk yield and/or fertility of a cow. Many diseases lower milk production (Detilleux et al., 1997; Rajala and Gröhn, 1998; Rajala-Schultz et al., 1999a) and it might be the low yield that triggers the decision to have the cow removed rather than the disease occurrence itself. Also, diseases can delay conception and lengthen the period of days open (Dhaliwal et al., 1996; Harman et al., 1996; Gröhn and Rajala-Schultz, 2000); open cows are more likely to leave the herd than pregnant ones.

Table 4. Effect of Infertility or Reproductive Disorders on The Percentage of Culling

\begin{tabular}{|c|c|c|c|c|c|c|c|}
\hline Disorders & Years & 1997-1999 & 2000-2002 & $2003-2005$ & 2006-2008 & 2009-2011 & $1997-2011$ \\
\hline Infertility & & $36 \%(10)$ & $30 \%(07)$ & $62 \%(29)$ & $65 \%(37)$ & $60 \%(24)$ & $55 \%$ (107) \\
\hline Abortion & & $25 \%(07)$ & $43 \%$ (10) & $15 \%(07)$ & $25 \%(14)$ & $25 \%(10)$ & $25 \%(48)$ \\
\hline Dystocia & & $18 \%(05)$ & $26 \%(06)$ & $21 \%(10)$ & $09 \%(05)$ & $13 \%(05)$ & $16 \%(31)$ \\
\hline Prolapse & & $14 \%(04)$ & $00 \%(00)$ & $02 \%(01)$ & $00 \%(00)$ & $03 \%(01)$ & $36 \%(06)$ \\
\hline Stillbirth & & $07 \%(02)$ & $00 \%(00)$ & $00 \%(00)$ & $02 \%(01)$ & $00 \%(00)$ & $23 \%(03)$ \\
\hline Total & & $100 \%$ (28) & $100 \%(23)$ & $100 \%(47)$ & $100 \%(57)$ & $100 \%(40)$ & $100 \%$ (195) \\
\hline
\end{tabular}

Table 5. Effect of Infection Disease on The Percentage of Culling

\begin{tabular}{|c|c|c|c|c|c|c|c|}
\hline Disorders & Years & 1997-1999 & $2000-2002$ & 2003-2005 & 2006-2008 & 2009-2011 & $1997-2011$ \\
\hline \multicolumn{2}{|c|}{ Hydatid Cyst } & 17 & $00 \%$ & $08 \%$ & $13 \%(01)$ & $06 \%$ & $09 \%(05)$ \\
\hline \multicolumn{2}{|c|}{ Parasitic Disease } & & $20 \%$ & $08 \%$ & $13 \%$ & & \\
\hline \multicolumn{2}{|c|}{ Pneumonia } & & & & & & \\
\hline \multicolumn{2}{|c|}{ Polmonary Abscess } & & & & & & $33 \%(18)$ \\
\hline \multicolumn{2}{|l|}{ Total } & (12) & 100 & (13) & $100 \%(16)$ & $100 \%(16)$ & $100 \%(54)$ \\
\hline
\end{tabular}

The culling rate in our study was lower than that reported by other sudies (Gröhn et al., 1998; Stevenson and Lean, 1998; Dutil et al., 1999; Whitaker et al., 2000). 
Results from Current experiment indicated that the reproductive status of a cow was the single most important factor in a farmer's culling decision. This is in agreement with similar studies, which have indicated that a failure to conceive at first service or a longer period of days open increases the risk of culling (Martin et al., 1982; Erb et al., 1985; Beaudeau et al., 1995). Also, Gröhn et al. (1998) reported that after a cow has conceived, her risk of culling decreases.

In contrast to other studies, metabolic and digestive track disorders constituted a considerable proportion of culling in the present study. According to the results of current study, Among other health-related culling reasons, those related to metabolic and digestive track disorders are the second most frequent. This is likely to be related to nutritional and feeding problems in the studied farm. Some dairy cow diseases related to metabolic and digestive track disorders occur only at or around calving (e.g., milk fever) (Gröhn et al., 2003). In the studies of Rajala-Schultz and Gröhn (1999a,b), milk fever increased the risk of culling at the time of their occurrence, and also at the end of lactation. In two main studies, cows with milk fever were found to be at greater risk of being culled within 45 days post-partum (Beaudeau et al., 1995; Gröhn et al., 1998). Most previous studies did not report any effect, maybe because the moment of culling within the lactation was not accounted for. A few studies investigated the effect of lameness on culling. Most reported no significant effect (Beaudeau et al., 1995). This is in agreement with current study findings. A possible explanation is that many foot problems stay on a subclinical level and perhaps do not play a major role in the culling decision. Less of $3 \%$ of dairy cows are culled because of foot disorders. According to the results of current study displaced abomasum accunted 09\% of metabolic and digestive track disposal. Displaced abomasum was a risk factor for culling in early lactation, and not later on (Geishauser et al., 1998; Gröhn et al., 1998). A possible explanation could be the decreased milk production following the occurrence of that event, that may indirectly lead to an increased risk of being removed (Geishauser et al., 1998).

Table 6. Effect of Udder Disorders on The Percentage of Culling

\begin{tabular}{|c|c|c|c|c|c|c|c|}
\hline Disorders & Years & 1997-1999 & $2000-2002$ & $2003-2005$ & $2006-2008$ & 2009-2011 & $1997-2011$ \\
\hline \multicolumn{2}{|c|}{ Subacute Mastitis } & $83 \%(05)$ & $100 \%(02)$ & $60 \%(03)$ & $100 \%(12)$ & $89 \%(08)$ & $88 \%(30)$ \\
\hline \multicolumn{2}{|c|}{ Rupture Breast } & $17 \%(01)$ & $00 \%(00)$ & $03 \%(02)$ & $00 \%(00)$ & $11 \%(01)$ & $12 \%(04)$ \\
\hline \multicolumn{2}{|l|}{ Total } & $100 \%(06)$ & $100 \%(00)$ & $100 \%(05)$ & $100 \%(12)$ & $100 \%(09)$ & $100 \%(34)$ \\
\hline
\end{tabular}

An increased risk of culling in cows which have experienced a mastitis is a classical finding, regardless of the differences between breeds, study Main periods at risk of being culled in case of mastitis were early lactation (Beaudeau et al., 1994; Gröhn et al., 1998) and dry period (Beaudeau et al., 1995). Despite a very low incidence rate, the very high risk associated with incidence rate, the very high risk associated with mastitis during the dry period can be explained by it's severity, possibly associated with a doubt on expected yield in the next lactation. However the risk of being culled after mastitis occurrence exists for all stages of lactation. The findings of current study confirm the results of pervious studies. The high impact on culling of teat injuries found by Beaudeau et al. (1994; 1995) might be because they prevent milking and cause mastitis. 
Table 7. Effect of Other Disorders on The Percentage of Culling

\begin{tabular}{|c|c|c|c|c|c|c|}
\hline Disorders $\quad$ Years & 1997-1999 & $2000-2002$ & $2003-2005$ & 2006-2008 & 2009-2011 & 1997-2011 \\
\hline Bone Fracture & $25 \%(01)$ & $33 \%(01)$ & $00 \%(00)$ & $20 \%(01)$ & $00 \%(00)$ & $19 \%(03)$ \\
\hline Vagal Syndrome & $00 \%(00)$ & $33 \%(01)$ & $50 \%(01)$ & $40 \%(02)$ & $50 \%(01)$ & $31 \%(05)$ \\
\hline Foreign Body & $50 \%(02)$ & $33 \%(01)$ & $50 \%(01)$ & $20 \%(01)$ & $50 \%(01)$ & $38 \%(06)$ \\
\hline Unknown & $25 \%(01)$ & $00 \%(00)$ & $00 \%(00)$ & $20 \%(01)$ & $00 \%(00)$ & $13 \%(02)$ \\
\hline Total & $100 \%(04)$ & $100 \%(03)$ & $100 \%(02)$ & $100 \%(05)$ & $100 \%(02)$ & $100 \%(16)$ \\
\hline
\end{tabular}

In contrast to other studies (Gröhn et al., 1998; Stevenson and Lean, 1998) reasons for involuntary culling such as infectious diseases constituted a considerable proportion of culls in our study. This is likely to be related to the diseases present in the herd or in the region, as there is a strong relationship between the existing diseases in a herd and culling rate (Gröhn et al., 1998; Stevenson and Lean, 1998).

\section{Conclusion}

In conclusion, The high percentage of involuntary culling due to health disorders especially infertility or reproductive disorders in dairy herds could contribute to economic loss, in the Torbat-e-Jam area. Therefore, in this area precaution measures should be taken into consideration for minimizing these kinds of costly culling through management approach to enhance dairy cows' nutritional and health performance in the herds.

\section{References}

Allaire, F. R., Sterwerf, H. E., \& Ludwick, T. M. (1977). Variations in removal reasons and culling rates with age for dairy females. J. Dairy Sci. 60, 254-267. http://dx.doi.org/10.3168/jds.S0022-0302(77)83862-9

Azizzadeh, M. (2011). Characterisation and pattern of culling in Holstein-Friesian dairy herds in Khorasan Razavi Province, Northeast of Iran. Veterinary Research Forum, 2(4), 254-258.

Beaudeau, F., Ducrocq, V., Fourichon, C., \& Seegers, H. (1995). Effect of disease on length of productive life of French Holstein dairy cows assessed by survival analysis. J. Dairy Sci, 78, 103-117. http://dx.doi.org/10.3168/jds.S0022-0302(95)76621-8

Beaudeau, F., Frankena, K., Fourichon, C., Seegers, H., Faye, B., \& Noordhuizen, J. P. T. M. (1994). Associations between health disorders of French dairy cows and early and late culling decision making within the lactation. Preventive Veterinary Medicine, 19, 213-231. http://dx.doi.org/10.1016/0167-5877(94)90090-6

Beaudeau, F., Henken, A., Fourichon, C., Frankena, K., \& Seegers, H. (1993). Associations between health disorders and culling of dairy cows: a review. Livest. Prod. Sci, 35, 213-236. http://dx.doi.org/10.1016/0301-6226(93)90094-X

Cobo-Abreu, R., Martin, S. W., Stone, J. B., \& Willoughby, R. A. (1979b). The rates and patterns of survivorship and disease in a university dairy herd. Can. Vet. J, 20, 177-183. 
Detilleux, J. C., Gröhn, Y. T., Eicker, S. W., \& Quaas, R. L. (1997). Effects of left displaced abomasum on test day milk yields of Holstein cows. J. Dairy Sci, 80, 121-126. http://dx.doi.org/10.3168/jds.S0022-0302(97)75919-8

Dhaliwal, G. S., Murray, R. D., \& Dobson, H. (1996). Effects of milk yield and calving to first service interval, in determining herd fertility in dairy cows. Anim. Reprod. Sci, 41, 109-117. http://dx.doi.org/10.1016/0378-4320(95)01441-1

Dutil, L., Fecteau, G., Bouchard, E., Du Tremblay, D., \& Paré, J. (1999). A questionnaire on the cow-calf herds in Québec. Can. Vet. J., 40: cow-calf herds in Québec. Can. Vet. J, 40, 649-656.

Erb, H. N., Smith, R. D., Oltenacu, P. A., Guard, C. L., Hillman, R. B., Powers, P. A., Smith, M. C., \& White, M. E. (1985). Path model of reproductive disorders and performance, milk fever, mastitis, milk yield, and culling in Holstein cows. J. Dairy Sci, 68, 3337-3349. http://dx.doi.org/10.3168/jds.S0022-0302(85)81244-3

Geishauser, T., Shoukri, M., Kelton, D., \& Leslie K. (1998). Analysis of survivorship after displaced abomasum is diagnosed in dairy cows. J. Dairy Sci, 81, 2346-2353. http://dx.doi.org/10.3168/jds.S0022-0302(98)70125-0

Gröhn, Y. T., Ducrocq, V., \& Hertl, J. A. (1997). Modeling the effect of a disease on risk of culling: an illustration of the use of time-dependent variables in survival analysis. J. Dairy Sci, 80, 1755-1766. http://dx.doi.org/10.3168/jds.S0022-0302(97)76109-5

Gröhn, Y. T., Eicker, S. W., Ducrocq, V., \& Hertl, J. A. (1998). Effect of diseases on culling in New York State Holstein dairy cows. J. Dairy Sci, 81, 966-978. http://dx.doi.org/10.3168/jds.S0022-0302(98)75657-7

Gröhn, Y. T., \& Rajala-Schultz, P. J. (2000). Epidemiology of reproductive performance in dairy cows. Anim. Reprod. Sci, 60, 605-614. http://dx.doi.org/10.1016/S0378-4320(00)00085-3

Gröhn, Y. T., Rajala-Schultz, P. J., Allore, H. G., DeLorenzo,M. A., Hertl, J. A., \& Galligan D. T. (2003). Optimizing replacement of dairy cows: modeling the effects of diseases. Preventive Veterinary Medicine, 61, 27-43. http://dx.doi.org/10.1016/S0167-5877(03)00158-2

Harman, J. L., Gröhn, Y. T., Erb, H. N., \& Casella, G. (1996). Event-time analysis of the effect of season of parturition, parity, and concurrent disease on parturition-to-conception interval in dairy cows. Am. J. Vet. Res, 57, 640-645.

Martin, S. W., Aziz, S. A., Sandals, W. C. D., \& Curtis, R. A., (1982). The association between clinical disease, production and culling in Holstein-Friesian cows. Can. J. Anim. Sci, 62, 633-640. http://dx.doi.org/10.4141/cjas82-073

McCullough, D. A., \& DeLorenzo, M. A. (1996b). Effects of price and management level on optimal replacement and insemination decisions. J. Dairy Sci, 79, 242-253. http://dx.doi.org/10.3168/jds.S0022-0302(96)76357-9

Milian-Suazo, F., Erb, H. N., \& Smith, R. D. (1988). Descriptive epidemiology of culling in 
dairy cows from 34 herds in New York State. Prev. Vet. Med, 6, 243-251. http://dx.doi.org/10.1016/0167-5877(88)90036-0

Rajala-Schultz, P. J., \& Gröhn, Y. T. (1998). Effects of dystocia, retained placenta and metritis on milk yield in Finnish Ayrshire cows. J. Dairy Sci, 81, 3172-3181. http://dx.doi.org/10.3168/jds.S0022-0302(98)75883-7

Rajala-Schultz, P. J., \& Gröhn, Y. T. (1999a). Culling of dairy cows. Part I. Effects of diseases on culling in Finnish Ayrshire cows. Prev. Vet. Med, 41, 195-208. http://dx.doi.org/10.1016/S0167-5877(99)00046-X

Rajala-Schultz, P. J., \& Gröhn, Y. T. (1999b). Culling of dairy cows. Part II. Effects of diseases and reproductive performance on culling in Finnish Ayrshire cows. Prev. Vet. Med, 41, 279-294. http://dx.doi.org/10.1016/S0167-5877(99)00045-8

Stevenson, M. A., \& Lean, I. J. (1998). Descriptive epidemiological study on culling and deaths in eight dairy herds. Australian Veterinary Journal, 76, 482-488. http://dx.doi.org/10.1111/j.1751-0813.1998.tb10188.x

Van Arendonk, J. A. M. (1985). Studies on the replacement policies in dairy cattle II. Optimum policy and influence of changes in production and prices. Livest Prod Sci, 13, 101-121. http://dx.doi.org/10.1016/0301-6226(85)90014-4

Van Arendonk, J. A. M. (1988). Management guides for insemination and replacement decisions. J. Dairy Sci, 71, 1050-1057. http://dx.doi.org/10.3168/jds.S0022-0302(88)79651-4

Whitaker, D. A., Kelly, J. M., \& Smith, S. (2000). Disposal and disease rates in 340 British dairy herds. Vet. Rec, 146, 363-367. http://dx.doi.org/10.1136/vr.146.13.363

\section{Copyright Disclaimer}

Copyright reserved by the author(s).

This article is an open-access article distributed under the terms and conditions of the Creative Commons Attribution license (http://creativecommons.org/licenses/by/3.0/). 